\title{
An Analysis of the Relationship between Scientific Epistemological Beliefs and Educational Philosophies: A Research on Formation Teacher Candidates
}

\author{
Ali Rıza Terzi", Nihat Uyangör \\ Department of Educational Sciences, Necatibey Education Faculty, Balikesir University, Turkey
}

Copyright $\subset 2017$ by authors, all rights reserved. Authors agree that this article remains permanently open access under the terms of the Creative Commons Attribution License 4.0 International License

\begin{abstract}
This research explores the relationship between scientific epistemological beliefs and educational philosophies of formation teacher candidates. The research was conducted in the summer pedagogical formation program at Balikesir University of Necatibey Education Faculty during the 2016-17 academic years. The research, conducted with 379 candidate teachers, indicates that teacher candidates hold a significantly high score in sub-dimensions of reasoning and in changeability of knowledge concerning scientific epistemological beliefs. The most adopted educational philosophies are progressive and reconstructionist philosophies of education. There is a significant difference between the viewpoints of teacher candidates in terms of gender in relation to both scientific epistemological beliefs and educational philosophies. Same difference also prevails between the teacher candidates' fields of study. Departmental difference is between Natural Sciences/Mathematics fields and Skill/Competence fields. The research has determined a low correlation between the teacher candidates' scientific epistemological beliefs and their educational philosophies. The research results support the results of the existing researches in the literature.
\end{abstract}

Keywords Epistemological Beliefs, Educational Philosophies, Teacher Candidate

\section{Introduction}

Scientific epistemological beliefs reflect the views of the individuals pertaining to science, its qualities, methodologies, and the individual's acquisition process. Schommer [1] defines epistemological beliefs as beliefs corresponding to the nature of knowledge. As much as the abundance of research on how these variables are constructed in the individuals' mind $[2,3,4,5]$, research has also been conducted on the relationship between these variables and the others $[6,7,8]$. Literature evinces that most of the research done on epistemological beliefs at the university level focus on teacher candidates [9].

Although there is research on the variable of educational philosophies, $[10,11,12,13]$ scarcity of research on this field is apparent particularly when it comes to the relationship between scientific epistemological beliefs and educational philosophies. The reason, one might argue, is that the variables of educational philosophies and epistemological beliefs belong to the same cluster.

This research investigates the relationship between epistemological beliefs and educational philosophy within the context of formation teacher candidates.

\section{Scientific Epistemological Belief}

The fact that there is a myriad of definition pertaining to the nature of scientific knowledge does not guarantee a common definition among the researches from different disciplines. One might argue that a lack of consensus resulted from a variety of viewpoints upheld by the disciplines on what science is and what the nature of science is formed.

The nature of science is considered as the epistemology of science. The nature of science is seen as the intersection of sub scientific disciplines such as history of science, sociology of science, and philosophy of science [14].

Disregarding the offstage parts, positivism obligated that knowledge had to be acquired through observation and quantification and that it based on facts [15]. This view, whose foundation was laid by A. Comte, is based on the law known as the law of three stages and identified as "theological, metaphysical and positivistic" [16]. It is argued that in the positivistic stage, far from any superstitious and metaphysical influence, scientific rules will prevail.

Cartesian dualism assumed that absolute knowledge can 
be extracted from the material and concrete world via experiment in general and this knowledge is based on mathematics and sciences in particular, separated the two worlds of physical reality (resextansa), and of values (rescogitas) definitely. Hence, the experimental results of science are universal since they have been obtained through precise objectivity, i.e. observation and experiment.

Positivism took its biggest step with logical positivism which built its methodological approach on validation. Validation manifests itself by way of induction; that is, reaching generalizations through individual observations $[17,18,5]$.

The assumption that positivism is a rational activity far from the scientific values has been put to contest by a radical viewpoint among whom Popper, Kuhn and Feyerabend [19] take the lead states that there is room for intuition and inspiration besides rules in science, that there cannot be an absolute and universal method, and that arguing for so will impede science. [20]. Popper (1985) assumes that the key point in being scientific is not verifiability but refutability [21], who finds Popper's refutability lacking, contends that subjective as well as objective factors prevail during both the initial and final phases of a scientific activity.

Lakatos especially challenges Kuhn's idea that the operative majority conducts theoretical choices in science. According to Lakatos, this choice is based on a collective or gang psychology. In addition, Lakatos argues that Kuhn renders scientific change mystical via denying logical explanations of scientific crises [22]. Kuhn also criticizes Lakatos; according to the former, Lakatos's theory shuts off a number of problems pertaining to the inevitability to make individual and collective decisions [23]. What distinguishes Lakatos is his comments on Feyerabend's anything-goes postmodernist approaches and equating Kuhn's paradigm change to religious conversion.

The ongoing discussion revolving around the questions on how science is conducted, where its limits begin and end, by which methods knowledge is acquired, is arguably a methodological discussion. Upon this premise, epistemological belief can be defined as the individual's private beliefs about what knowledge is how it is acquired and known. Thus [9], conveys that epistemological beliefs reflect the individual views and questions regarding what knowledge is, how it is acquired, what its certainty, its limits and criteria are, whether knowledge happens outside the student or imposed on them by the experts.

Research shows that scientific epistemological beliefs have determining effects particularly on students' preferred teaching-learning approaches, learning strategies they use, and on their ways of interpreting knowledge. As such, epistemological beliefs significantly influence individuals' cognitive and above cognitive processes [24, 25].

\section{Philosophies of Education}

One of the definitions of philosophy is that philosophy is a research of a collective view, universal explanatory experiment on nature [26]. Kant defines philosophy as "a form of mental activity claiming to justify itself based on logical reasons" [27]. Since the foundational scope of philosophy such as knowledge and value also intersect with the scope of education, it is inevitable for them not to have a common ground, whose generic name is philosophy of education.

An individual's education is shaped through the target philosophy or philosophies according to which a whole education system is organized. Hence, the relationship between philosophy and education resembles the relationship between the visually impaired and the service $\operatorname{dog}$ [15]. Yet, the philosophical trends resulting from the relationship between education and philosophy and related practices in education systems manifest themselves in various forms.

The perennialism heavily influenced by idealism, where education is supposed to be an intellectual endeavor, argues that education should be founded on permanent principles and facts. Although essentialism depends heavily on realist philosophy, it contends that the human being as a social and cultural entity is not equipped with any information from birth but acquires knowledge afterwards through induction. Solely through the lens of these two philosophies, these principles will be differently implemented at school. Whereas in perennialism, courses are made to be memorized by the learner, according to essentialism there is an outer world independent of the human and its rules to be obeyed. The main reason for the student to continue to attend school is to get to know this world and to learn to adapt it. Knowledge of this world cannot be coincidentally acquired but through a logical organization of the subjects. Progressive education is founded on the idea that change is the sole unchanging object. It situates the student at the center of the learning philosophy and designs student-centered methods. When it focuses on how the student should think, it compels school to become life itself. When re-constructionist focuses on building a new society, they intersect with progressives on taking democratic practices as a principle $[7,28,29,30,31$, 15].

This research has investigated the relationship between epistemological beliefs and philosophies of education within the context of formation teacher candidates. Investigating the relationship between the epistemological beliefs and educational philosophies of teacher candidates might give clues about the diversity of in class practices when they become teachers. Furthermore, conducting the research on the formation students from non-educational departments of different universities might provide generalization as this will manifest divergent views on the nature of science. Hence, this research seeks answers to the below questions:

1. (a) What is the level of scientific epistemological beliefs of teacher candidates?

(b)What are the educational philosophies they have 
adopted?

2. According to the gender of teacher candidates, do their

(a) scientific epistemological beliefs

(b) educational philosophical tendencies vary significantly?

3. According to the fields of study of teacher candidates, do their

(a) scientific epistemological beliefs, and

(b) educational philosophical tendencies vary significantly?

4. Is there a significant correlation between the epistemological beliefs and educational philosophies of teacher candidates?

\section{Materials and Methods}

\subsection{Research Model}

This research employs relational screening model. Relational screening model is the research model that aims to determine the existence and/or level of mutual change between two or more variables [32].

\subsection{Study Group}

The study group consists of 750 students divided into 15 groups in the pedagogical formation program during the summer semester of 2016-2017 academic years at Balikesir University of Necatibey Education Faculty. The data collection tools are applied to the mentioned groups, and the data retrieved from the scales that were fully answered by 379 students is used for this research. These data constitute $50.5 \%$ of the entire study group. When the distribution of pedagogical formation students that constitute the study group are examined based on gender, it is seen that female participants constitute $68.9 \%(n=261)$ and male participants constitute $31.1 \%(\mathrm{n}=118)$ of the study group. When the distribution of the students are examined based on their fields of study, participants from Social Sciences fields constitute 9.8\% $(\mathrm{n}=37)$, participants from Natural Sciences/Mathematics fields constitute $75.5 \%$ $(\mathrm{n}=286)$, and participants from Skill/Competence fields (Music, Arts, Physical Education) constitute 14.8\% ( $n=56)$ of the entire study group.

\subsection{Data Collection Tools}

Scientific Epistemological Beliefs Scale and Determining the Tendencies towards Educational Philosophies Scale are used in this research.

Scientific Epistemological Beliefs Scale is a scale that is developed by Elder (1999) and adopted into Turkish by Tüken and Karadağ (2010). The scale consists of 25 items and 4 dimensions written in the form of a 5 point agreement Likert-type scale. The authority and accuracy dimension consists of nine, knowledge production process dimension consists of six, source of knowledge dimension consists of four, reasoning and changeability of knowledge dimensions consist of three items each. Authority and accuracy factor includes beliefs regarding that knowledge exists out of the individual, and knowledge is absolute. Knowledge production process addresses the empirical foundation in the construction of scientific knowledge. Source of knowledge factor addresses the beliefs on the accuracy of information that the individual obtains from the resources other than himself. Reasoning factor addresses the beliefs regarding the place of logic and scientific curiosity in the construction of knowledge. Changeability of knowledge addresses beliefs regarding the nature of knowledge as inexact.

The internal consistency coefficient (Cronbach Alpha) of the scale is stated between .57 and .86 for the dimensions, and .82 for the general scale. The test-retest correlation coefficients of the scale vary between .374 and .758 . The total variance explained by the scale for the four dimensions is $52.77 \%$. The compliance parameters of the scale regarding confirmatory factor analysis determined by the researchers are as follows: GFI 0.78 , AGFİ, 0.75 , PGFI், 0.68 , RMSA 0.07 CFİ, $0.86, \chi^{2} / d f 2.06$. In this research, Cronbach Alpha is applied as the reliability analysis of the scale, and found as $\mathrm{a}=76$ for the general scale.

\subsection{Determining the Tendencies towards Educational Philosophies Scale}

Determining the Tendencies towards Educational Philosophies Scale developed by Uyangör, Atıcı, and Börekçi [33] is used in this research. The scale consists of 4 sub-dimensions and 36 items that involve educational philosophies. The item-total correlations of the scale stated by the researchers vary between .31 and .55

The reliability analysis is stated as $a=.84$ for the total scale. Cronbach's Alpha is applied to the scale as reliability analysis in this research as well, and $\mathrm{a}=.75$ is found for the general scale.

\section{Findings}

As can be seen in Table-1 which shows scientific epistemological beliefs and educational philosophies of the participants, the first sub-problem of this study, teacher candidates scored highest in reasoning regarding epistemological beliefs ( $X=4.29$; ss:74), followed by the closest mean score in the changeability of knowledge $(\mathrm{X}=4.18$; ss:80).

On the other hand, the lowest score was measured for the source of knowledge ( $X=2.60$; ss:74). With regards to educational philosophies, formation teacher candidates scored in favor of reconstructionism ( $X=4.47$; ss:50). The 
second highest score was observed for progressivism $(\mathrm{X}=4.33$; ss:51). The lowest mean score of formation teacher candidates regarding educational philosophies was in essentialism $(X=2.67$; ss:71).

Table 1. Mean scores regarding the epistemological beliefs and educational philosophies of the formation teacher candidates

\begin{tabular}{|c|c|c|c|}
\hline Dimensions & $\mathrm{N}$ & $\overline{\mathrm{X}}$ & $\mathrm{Ss}$ \\
\hline Authority and accuracy & 379 & 2,14 & .73 \\
\hline $\begin{array}{c}\text { Knowledge production } \\
\text { process }\end{array}$ & 379 & 3,94 & .62 \\
\hline Source of knowledge & 379 & 2,60 & .85 \\
\hline Reasoning & 379 & 4,29 & .74 \\
\hline $\begin{array}{c}\text { Changeability of } \\
\text { knowledge }\end{array}$ & 379 & 4,18 & .80 \\
\hline Perennialism & 379 & 3,42 & .61 \\
\hline Essentialism & 379 & 2,67 & .71 \\
\hline Progressivism & 379 & 4,33 & .51 \\
\hline Reconstructionism & 379 & 4,47 & .50 \\
\hline
\end{tabular}

As can be seen in Table 2, there is a significant difference in favor of male candidates in the authority and accuracy sub-dimension of formation teacher candidates' scientific epistemological beliefs (Average rank Male= 212.08; Female $=180.02$ ). On the other hand, there is a significant difference in favor of female candidates in the sub-dimension of reasoning (Average rank: $F=198,87$; $\mathrm{M}=170,39$ ). With regards to philosophical tendencies, while a significant difference exists in favor of male teacher candidates in essentialism, a significant difference exists in favor of female candidates in the sub dimensions of progressivism and reconstructionism. In other words, while male candidates adopt more of essentialist educational philosophies, female teacher candidates adopt more of progressive and reconstructionist philosophies.

Table 2. Mann Witney-U test for the differences in scientific epistemological belief and philosophical tendency based on gender

\begin{tabular}{|c|c|c|c|c|c|}
\hline \multirow{2}{*}{ Authority and accuracy } & gender & $\mathrm{N}$ & $\begin{array}{c}\text { average } \\
\text { rank }\end{array}$ & $\mathrm{z}$ & $\mathrm{p}$ \\
\hline \multirow{2}{*}{ Reasoning } & Female & 261 & 180,02 & -2.461 & $.008^{* *}$ \\
\cline { 2 - 7 } & Male & 118 & 212,08 & & \\
\cline { 2 - 6 } & Memale & 261 & 198,87 & -2.394 & $.017^{*}$ \\
\hline \multirow{2}{*}{ Essentialism } & Female & 261 & 179,99 & -2649 & $.008^{* *}$ \\
\cline { 2 - 7 } & Male & 118 & 212,14 & & \\
\hline \multirow{2}{*}{ Progressivism } & Female & 261 & 200,61 & -2.815 & $.005^{* *}$ \\
\cline { 2 - 7 } & Male & 118 & 166,52 & & \\
\hline \multirow{2}{*}{ Reconstructionism } & Female & 261 & 201,96 & -3.178 & $001^{* *}$ \\
\cline { 2 - 6 } & Male & 118 & 163,54 & & \\
\hline
\end{tabular}

${ }^{*} \mathrm{p}<05 * * \mathrm{p} .<01$

When the scientific epistemological beliefs are compared based on the fields of the formation teacher candidates (Table-3), a significant difference in opinion becomes apparent in the sub-dimensions of authority and accuracy $(\mathrm{F}=5.352 ; \mathrm{p}<.01)$, knowledge production process $(\mathrm{F}=3.665 ; \mathrm{p}<.05)$, and source of knowledge $(\mathrm{F}=3.143$; $\mathrm{p}<.05$ ). This difference is between candidates from Skill/ Competence fields and Natural Sciences/Mathematics fields. The average scores of candidates from Skill/Competence fields (e.g. Arts, Music, and Physical Education) were higher than the scores of candidates from Natural Sciences/Mathematics fields.

Table 3. Anova for the differences in scientific epistemological beliefs based on the fields of formation teacher candidates

\begin{tabular}{|c|c|c|c|c|c|c|c|c|}
\hline Sub-dimensions & Field of Study & $\mathrm{N}$ & $\overline{\mathrm{X}}$ & Ss & $\mathrm{F}$ & $\mathrm{Sd}$ & $\mathrm{p}$ & $\begin{array}{c}\text { Fark } \\
\text { Tukey }\end{array}$ \\
\hline \multirow{3}{*}{ Authority and accuracy } & (1) Soc. Sci. & 37 & 2.07 & .69 & \multirow{3}{*}{5.352} & \multirow{3}{*}{376} & \multirow{3}{*}{$005^{* *}$} & \multirow{3}{*}{$2-3$} \\
\hline & (2) Nat.Sci./Math & 286 & 2.09 & .74 & & & & \\
\hline & (3) Skill & 56 & 2.43 & .64 & & & & \\
\hline \multirow{3}{*}{ Knowledge production process } & (1) Soc. Sci. & 37 & 4.06 & .61 & \multirow{3}{*}{3.665} & \multirow{3}{*}{376} & \multirow{3}{*}{$.027^{*}$} & \multirow{3}{*}{$2-3$} \\
\hline & (2) Nat.Sci./Math & 286 & 3.89 & .62 & & & & \\
\hline & (3) Skill & 56 & 4.11 & .60 & & & & \\
\hline \multirow{3}{*}{ Source of knowledge } & (1) Soc. Sci. & 37 & 2.77 & .86 & \multirow{3}{*}{3.143} & \multirow{3}{*}{376} & \multirow{3}{*}{$044^{*}$} & \multirow{3}{*}{$2-3$} \\
\hline & (2) Nat.Sci./Math & 286 & 2.54 & .85 & & & & \\
\hline & (3) Skill & 56 & 2.81 & .84 & & & & \\
\hline \multirow{3}{*}{ Reasoning } & (1) Soc. Sci. & 37 & 4.41 & .79 & \multirow{3}{*}{588} & \multirow{3}{*}{376} & \multirow{3}{*}{--} & \\
\hline & (2) Nat.Sci./Math & 286 & 4.27 & .75 & & & & \\
\hline & (3) Skill & 56 & 4.29 & .64 & & & & \\
\hline \multirow{3}{*}{ Changeability of knowledge } & (1) Soc. Sci. & 37 & 4.21 & .77 & \multirow{3}{*}{124} & \multirow{3}{*}{376} & \multirow{3}{*}{--} & \\
\hline & (2) Nat.Sci./Math & 286 & 4.18 & .80 & & & & \\
\hline & (3) Skill & 56 & 4.13 & .79 & & & & \\
\hline
\end{tabular}

$* \mathrm{p}<.05 * * \mathrm{p} .<01$ 
Table 4. Anova for the differences in educational philosophies based on the fields of formation teacher candidates

\begin{tabular}{|c|c|c|c|c|c|c|c|c|}
\hline Sub-dimensions & Field of Study & $\mathrm{N}$ & $\overline{\mathrm{X}}$ & Ss & $\mathrm{F}$ & $\mathrm{Sd}$ & $\mathrm{p}$ & Fark Tukey \\
\hline \multirow{3}{*}{ Perennialism } & (1) Soc. Sci. & 37 & 3.54 & .66 & \multirow{3}{*}{3.433} & \multirow{3}{*}{376} & \multirow{3}{*}{$.03 *$} & \multirow{3}{*}{$2-3$} \\
\hline & (2) Nat.Sci./Math & 286 & 3.57 & .62 & & & & \\
\hline & (3) Skill & 56 & 3.37 & .49 & & & & \\
\hline \multirow{3}{*}{ Essentialism } & (1) Soc. Sci. & 37 & 2.70 & .82 & \multirow{3}{*}{5.244} & \multirow{3}{*}{376} & \multirow{3}{*}{$.006 * *$} & \multirow{3}{*}{$2-3$} \\
\hline & (2) Nat.Sci./Math & 286 & 2.62 & .69 & & & & \\
\hline & (3) Skill & 56 & 2.95 & .71 & & & & \\
\hline \multirow{3}{*}{ Progressivism } & (1) Soc. Sci. & 37 & 4.19 & .49 & \multirow{3}{*}{2.872} & \multirow{3}{*}{376} & \multirow{3}{*}{--} & \\
\hline & (2) Nat.Sci./Math & 286 & 4.37 & .50 & & & & \\
\hline & (3) Skill & 56 & 4.27 & .54 & & & & \\
\hline \multirow{3}{*}{ Reconstructionism } & (1) Soc. Sci. & 37 & 4.39 & .44 & \multirow{3}{*}{1.447} & \multirow{3}{*}{376} & \multirow{3}{*}{--} & \\
\hline & (2) Nat.Sci./Math & 286 & 4.49 & .49 & & & & \\
\hline & (3) Skill & 56 & 4.39 & .60 & & & & \\
\hline
\end{tabular}

${ }^{*} \mathrm{p}<.05 * * \mathrm{p} .<01$

Table 5. Relationship between scientific epistemological beliefs and educational philosophies

\begin{tabular}{|c|c|c|c|c|}
\hline Dimensions & Perennialism & Essentialism & Progressivism & Reconstructionism \\
\hline Authority and accuracy & $.247^{* *}$ & $.287^{* *}$ & -.066 &. .023 \\
\hline Knowledge production process & $113^{*}$ & .025 & $.194^{* *}$ & $.205^{* *}$ \\
\hline Reasoning & -.011 & $-.152^{* *}$ & $.241^{* *}$ & $.241^{* *}$ \\
\hline Source of knowledge & $248^{* *}$ & $.242^{* *}$ & -.061 & -.050 \\
\hline Change ability of knowledge & -.032 & $-.150^{* *}$ & $.260^{* *}$ & $.252^{* *}$ \\
\hline
\end{tabular}

$* \mathrm{p}<.05 * * \mathrm{p} .<01$

As can be seen in Table-4 that shows the philosophical tendencies of formation teacher candidates based on their fields of study, their opinions significantly differ in perennialism $(\mathrm{F}=3.433 ; \quad \mathrm{p}<.05)$ and essentialism $(\mathrm{F}=5.244 ; \mathrm{p} .<01)$. This difference is between Skill/Competence and Natural Sciences/ Mathematics fields. While teacher candidates from Natural Sciences/ Mathematics fields adopt more of perennialist educational philosophies $\quad(X=3.57 ; \quad \mathrm{ss}=.62), \quad$ candidates from Skill/Competence fields adopt more of essentialist educational philosophies $(\mathrm{X}=2.95$; $\mathrm{ss}=.71)$.

Based on the findings in Table-5, low but mostly statistically significant correlation $(\mathrm{p}<. .01)$ between scientific epistemological beliefs and educational philosophies can be indicated. That is to say authority and accuracy correlated with perennialism $(\mathrm{r}=.247 ; \mathrm{p} .<.01)$ and essentialism $(\mathrm{r}=287 ; \quad \mathrm{p} .<.01)$; knowledge production process correlated with perennialism $(r=113: \mathrm{p}<.05)$, progressivism $(\mathrm{r}=194 ; \mathrm{p}<.0)$ and reconstructionism $(\mathrm{r}=205$; $\mathrm{p}<01)$. While reasoning showed a negative correlation with essentialism $(\mathrm{r}=-152 ; \mathrm{p}<.01)$, and positive correlation with progressivism $(\mathrm{r}=241 ; \mathrm{p}<.01)$ and reconstructionism $(\mathrm{r}=241 ; \mathrm{p}<.01)$, source of knowledge showed a positive correlation with perennialism $(\mathrm{r}=248 ; \mathrm{p}<01)$ and essentialism $(\mathrm{r}=242 ; \mathrm{p}<01)$. Finally, changeability of knowledge correlated negatively with essentialism ( $\mathrm{r}=-150$; $\mathrm{p}<01)$ and positively with progressivism and reconstructionism $(\mathrm{r}=260 ; \mathrm{p}<.01 ; \mathrm{r}=252 ; \mathrm{p}<01)$.

\section{Discussion and Conclusions}

This research in which the relationship between scientific epistemological beliefs and educational philosophies of formation teacher candidates were examined reveals that teacher candidates scored highest in the sub-dimensions of change ability of knowledge and reasoning and lowest in the sub-dimensions of source of knowledge within the scope of scientific epistemological beliefs. These opinions of teacher candidates are in accordance with modern scientific thought. The high mean score in the sub-dimension of reasoning also indicates the strong belief that teacher candidates hold towards the inquiry dimension of the construction of knowledge. Meanwhile, teachers' having the lowest mean score in the sub-dimension of authority and accuracy requires saying that the inquiring viewpoints of teacher candidates still prevail. In that, the authority and accuracy sub-dimension of scientific epistemological belief supposes that absolute truth exists, knowledge originates from a resource other than the individual and resides in authorities.

Formation teacher candidates adopt progressivism and reconstructionism the most and essentialism the least. From the essentialist education perspective, the facts that teacher exists in class as authority but that teacher 
candidates do not adopt this thought- essentialism has the lowest mean score in this research- subsume the results under a consistent ground. Having said that, the significantly higher mean score of perennialism than essentialism is one of the results that will cause problems in the interpretation of the research. This is because if an inquiring scientific mind puts forward perennialist philosophy that has underlying criteria such as absolute truth, omnitemporal universal knowledge, and innate knowledge, it can be related to the fact that these concepts have not been fully grasped by the formation teacher candidates. It can be suggested that this is because the data collection tools were given to the formation teacher candidates in the beginning of their education. Research results supporting this conclusion can be found in the literature. Indeed, Biçer, Er, and Özel [7] observed that while social science students adopted more of a perennialist philosophy in the first years of college, their beliefs towards this philosophy weakened in the last years of college. This finding of the research regarding the philosophical tendencies of formation teacher candidates is in accordance with Aslan [30] and Biçer, Er, and Özel [7].

The research indicates significant differences between the viewpoints of teacher candidates in terms of gender. While there exists a significant difference in favor of male candidates with regards to authority and accuracy sub-dimension of formation teacher candidates' epistemological beliefs, there exists a significant difference in favor of female candidates when it comes to the reasoning sub-dimension. Male teacher candidates adopt more of an essentialist philosophy and female teacher candidates more of progressive and reconstructionist educational philosophies. However, opposite findings can be encountered within the literature. For instance, Doğanay and Sarı [35]; Ilgaz, Bülbül and Çuhadar [36] obtained results indicating that gender is not a differentiating variable in terms of educational philosophies. Likewise, Çelik and Orçan [10] also identified that gender did not have a determining effect regarding educational philosophies. Nevertheless, the researches of Eroğlu and Güven [37]; Beytekin and Kadı [38]; Çakmak, Bulut, and Taşkıran [39] supports our research results. It is apparent that there is not a consensus on the results of researches on gender.

When the sub-dimensions of scientific epistemological beliefs based on their fields of study are examined, formation teacher candidates have significantly different viewpoints in authority and accuracy, knowledge production, and source of knowledge sub-dimensions. This difference is between students from Natural Sciences/Mathematics fields and Skill/ Competence fields. This finding of the research does not correspond to the research results of Doğanay and Sarı [35] but shows similarities with the research results of Kürşad [8].

Viewpoints of formation teacher candidates on perennialist and essentialist philosophies vary significantly when their philosophical tendencies are examined based on their fields of study. While teacher candidates from Natural Sciences/Mathematics fields are more perennialists, teacher candidates from Skill/Competence fields are more essentialists. This is one of the most interesting results of the research. The fact that teacher candidates of Natural Sciences/Mathematics fields do not adopt essentialist approach that also includes inductive method to access knowledge can be stemmed from the circumstance that teacher candidates did not fully grasp what is what in terms of educational philosophies. The finding that educational philosophies of teacher candidates differ according to their fields of study has similar aspects to the findings of Beytekin and Kadı [38]; Çetin, İlhan and Arslan [11]; and Tümkaya [40].

The research determined low positive correlations between scientific epistemological beliefs and educational philosophies and negative significant correlations in some of them. Especially the positive correlation, even though low, is significant between the sub-dimensions of authority and accuracy, source of knowledge and perennialist, essentialist educational philosophies. This is because permanent universal truths and the authority of teacher with regards to knowledge can be put forward within this context. If knowledge gained from books and teachers are accepted to be always true, this will accordingly evoke perennialist and essentialist educational philosophies. Since the existence of a positive significant correlation between reasoning and progressivism and reconstructionism requires an inquiring mind, this mode of relation is as it should be.

One of the limitations of the research can be its application on a very limited study group and at a time period when the educational concepts were not yet fully grasped by the participants. It can be suggested that the application of the research is extended over a period of time within the formation program and is done comparatively with the students of the school of education.

\section{REFERENCES}

[1] Schommer, M. (1990). Effects of beliefs about the nature of knowledge on comprehension. Journal of Educational Psychology, 82(3), 498-504.

[2] Bıkmaz, F. (2017). Öğretmen adaylarının öğretme-öğrenme anlayışları ve bilimsel epistemolojik inançlarının araştırılması: Boylamsal bir çalışma, Eğitim Bilim, 42(189), 183-196

[3] Meral, M. \& Çolak, E. (2009). Öğretmen adaylarının epistemolojik inançlarının incelenmesi, Ondokuz Mayıs Üniversitesi Eğitim Fakültesi Dergisi, 27, 129-146

[4] Öztürk Önen F. (2016). Bilimsel Epistemolojik İnançlar, Bilimsel Bilginin Doğası Hakkındaki Görüşler ve Bilimsel Tutumlar Üzerine Bir Çalışma: Abu Dhabi Örneği, $M S K U$ Ĕ̌itim Fakültesi Dergisi, 3(2), 16-29 
[5] Terzi, A. R. (2005). Üniversite öğrencilerinin bilimsel epistemolojik inançları üzerine bir araştırma. Afyon Kocatepe Üniversitesi Sosyal Bilimler Enstitüsü Dergisi, 7(2), 298-311.

[6] Başbay,M.(2013). Epistemolojik inancin eleştirel düşünme ve üstbiliş ile ilişkisinin yapısal eşitlik modeli ile incelenmesi, Eğitim Bilim, 38(169), 249-262

[7] Biçer, B., Er, H. \& Özel, A. (2013). Öğretmen adaylarının epistemolojik inançları ve benimsedikleri eğitim felsefeleri arasındaki ilişki. Eğitimde Kuram ve Uygulama, 9(3), 229-242.

[8] Kürşad, M. Ş. (2015). Bilimsel araştırmaya yönelik tutum ve epistemolojik inanç arasındaki ilişkinin incelenmesi. Abant İzzet Baysal Üniversitesi Eğitim Fakültesi Dergisi, 15(2), $217-246$.

[9] Yeşilyurt, E. (2013). İlköğretim okulu öğrencilerinin bilimsel epistemolojik inançları, International Journal of Social Science 6 (1), 1587-1609

[10] Çelik, R. \& Orçan, F. (2016). Öğretmen adaylarının eğitim inançları üzerine bir çalışma, Eğitimde Kuram ve Uygulama, 12(1), 63-77

[11] Çetin, B, İlhan, M. \& Arslan, S. (2012). Öğretmen adaylarının benimsedikleri eğitim felsefelerinin çeşitli değişkenler acısından incelenmesi. International Journal of Social Science, 5(5), 149-170.

[12] Demir, S. \& Akınoğlu, O. (2010). Epistemolojik inanışlar ve öğretme öğrenme süreçleri. M.Ü. Atatürk Eğitim Fakültesi Eğitim Bilimleri Dergisi. 32, 75 - 93.

[13] Duman, B. \& Ulubey, Ö. (2008). Öğretmen adaylarının benimsedikleri eğitim felsefelerinin öğretim teknolojilerini ve interneti kullanma düzeylerine etkisi ile ilgili görüşleri. Muğla Üniversitesi Sosyal Bilimler Enstitüsü Dergisi, 20, 95-114

[14] Bayır,E.\& Çakııı,Y.\& Atalay, Ertaş Ö.(2016) Fen Bilimleri Öğretmenlerinin Bilimin Doğasına İlişskin Görüşleri: Bilişsel Harita Örneği, Kastamonu Ĕgitim Fakültesi Dergisi, 24(3), 1419-1436

[15] Terzi,A.R.(2010).Eğitim Bilimine Giriş (2.baskı) Ankara: Detay Yayıncilik

[16] Doğan, N., Çakıroğlu, J., Çavuş, S., Bilican, K., \& Arslan, O. (2011). Öğretmenlerin bilimin doğası hakkındaki görüşlerinin geliştirilmesi: Hizmetiçi eğitim programının etkisi. Hacettepe Üniversitesi Eğitim Fakültesi Dergisi, 40,127-139

[17] Demir, Ö. (1997) Bilim Felsefesi, Ankara:Vadi Yayınlar1.

[18] Özlem, D. (1998) Evrensellik Mitosu ve Sosyal Bilimler, Bora, Tanıl-Sökmen, Semih- Şahin, Kaya (Der.), Sosyal Bilimleri Yeniden Düşünmek, İstanbul: Metis Yayınları, ss. 53-66.

[19] Feyerabend, P. K. (1989). Yönteme Hayır.A.İnam (Çev.), İstanbul: Ara Yayıncilık.

[20] Popper K. (1985) Tarihselciliğin Sefaleti, İstanbul. İnsan Yayınları

[21] Kuhn, T. S. (1982) Bilimsel Devrimlerin Yapısı, N. Kuyaş (Çev.), İstanbul: Alan Yayıncılık.

[22] Bat1, K (2013). Fen eğitiminde bilimsel yontem süreci öğretimi üzerine bir inceleme: Pozitivizmden anarșist bilgi kuramına, Pamukkale Üniversitesi Eğitim Fakültesi Dergisi, 34, $211-226$

[23] Atmaca, T. (2017). Lakatos'un Bilim Felsefesinde Rasyonellik,http://www.tlck.org.tr/wp-content/uploads/201 7/02/TLCKIII.V.1.pdf (Erişim tarihi:18.07.2017)

[24] Deryakulu, D.\& B1kmaz, F. H. (2003) Bilimsel epistemolojik inançlar ölçeğinin geçerlik ve güvenirlik çalışması, Eğitim Bilimleri ve Uygulama, 4, 244-257

[25] Schommer, M. (1994). Synthesizing epistemological belief research: Tentative understandings and provocative confusions. Educational Psychology Review, 6 (4), 293-319

[26] Weber, A. (1991) Felsefe Tarihi. Çev. (H. Vehbi Eralp) İstanbul: Sosyal Yayınları.

[27] Arslan, A. (1998). Felsefeye Giriş. Ankara: Vadi Yayınları

[28] Bilhan, S. (1991). Eğitim Felsefesi. Ankara: A. Ü. Eğitim Bilimleri Fakültesi Yayınları

[29] Ergun M. (2001). Eğitimin Felsefi Temelleri, Öğretmenlik Mesleğine Giriş. (Ed.Ö. Demirel \& Z.Kaya) Ankara: PegemA Yayıncılık

[30] Gutek, G.L. (2006). Eğitim Felsefesi ve İdeolojik Yaklaşımlar. (Çev.N.Kale) Ankara: Ütopya Yayınevi

[31] Sönmez, V. (2002). Eğitim Felsefesi, Ankara: An1 Yayıncilık

[32] Karasar, N. (2014). Bilimsel Araştırma Yöntemi (26.Bask1). Ankara Nobel Yayıncılık

[33] Uyangör, N. Atıcı, S.\& Börekçi, C.(2016).An analysis of educational philosophies and International Journal of Current Research, 8, (04), 30100-30106.

[34] Aslan, S. (2017). Sınıf Öğretmenlerinin Eğitim İnançlarının Çeşitli Değişkenler Açısından İncelenmesi, Kastamonu Eğitim Dergisi, 25(4), 1453-1468

[35] Doğanay, A. \& Sarı, M. (2003). Ġlköğretim Öğretmenlerinin Sahip Oldukları Eğitim Felsefelerine İlişkin Algılarının Değerlendirilmesi Öğretmenlerin Eğitim Felsefeler, Türk Ĕgitim Bilimleri Dergisi, 1(3), 321-337

[36] Ilgaz, G., Bülbül, T. \& Çuhadar, C. (2013). Öğretmen adaylarının eğitim ġnançları ile öz-yeterlik algıları arasındaki ilişkinin incelenmesi. Abant İzet Baysal Üniversitesi Eğitim Fakültesi Dergisi, 13(1), 50-65.

[37] Eroğlu S. E. \& Güven K. (2006). Üniversite öğrencilerinin epistemolojik inançlarının bazı değişkenler açısından incelenmesi. Selçuk Üniversitesi Sosyal Bilimler Enstitüsü Dergisi, 16, 295-312.

[38] Beytekin, O. F., \& Kadı, A. (2015). Öğretmen adaylarının eğitim inançları ve değerleri üzerine bir çalışma. The Journal of Academic Social Science Studies, 31, 327-341.

[39] Çakmak, Z., Bulut, B. \& Taşkıran, C. (2016). Sosyal Bilgiler Öğretmen Adaylarının Eğitim İnançlarına Yönelik Görüşlerinin Çeşitli Değişkenler Açısından İncelenmesi. Abant İzzet Baysal Üniversitesi Eğitim Fakültesi Dergisi, Cilt 16, (USBES Özel Sayı II), 1190-1205

[40] Tümkaya, S. (2012). Üniversite öğrencilerinin epistemolojik inançlarının cinsiyet, sınıf, eğitim alanı, akademik başarı ve ögrrenme stillerine göre incelenmesi, Kuram ve Uygulamada Eğitim Bilimleri, 12(1), 75-95. 